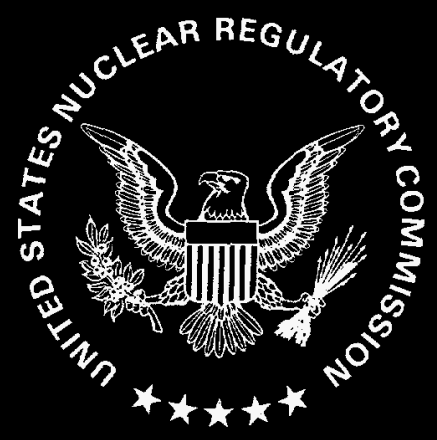

\title{
Office of the Inspector General
}

U.S. Nuclear Regulatory Commission

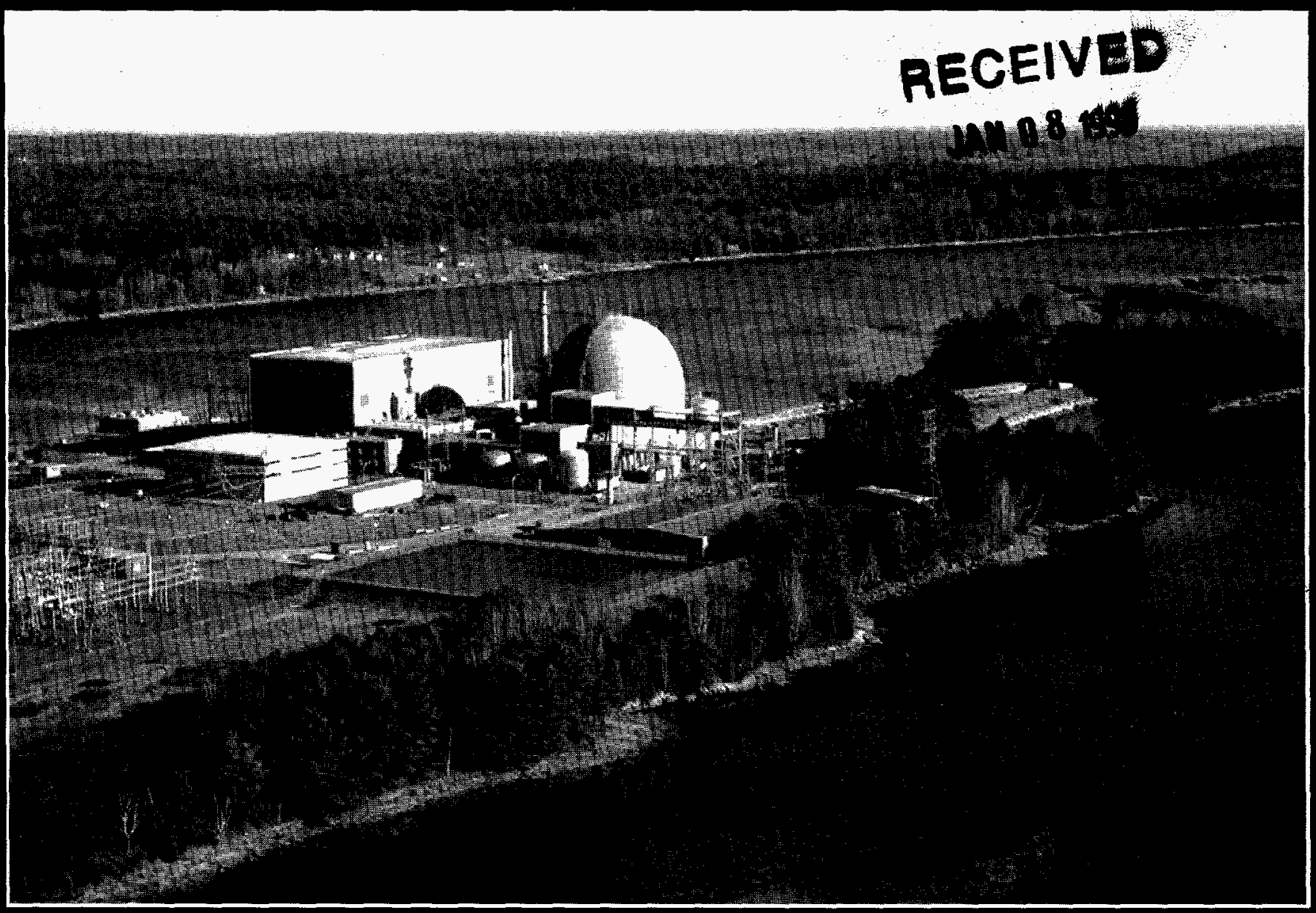

\section{Semiannual Report}

April 1, 1997 - September 30, 1997 


\section{NUREG-- $\left.1415-V_{0}\right) \cdot 10-N_{0} .1$}

\section{MEMORANDUM TO THE CHAIRMAN}

I am pleased to submit the Office of Inspector General's (OIG's) Semiannual Report to the U.S. Congress, which covers significant OIG activities during the period of April 1, 1997, through September 30, 1997. This report complies with Section 5 of the Inspector General Act of 1978, as amended.

During this reporting period, our office completed five performance and financial audits, and two special evaluations addressing the Nuclear Regulatory Commission's (NRC's) programs. We also analyzed 21 contract audit reports issued by the Defense Contract Audit Agency. The contract audit work resulted in questioning \$131,329 in costs and identifying an additional $\$ 32,513$ as funds that could be put to better use. As a result of the audit work, we made 11 recommendations and suggestions to NRC management. During this period, 30 investigations and 4 event inquiries were completed.

In carrying out the OIG's oversight responsibilities, we appreciate the cooperation and consideration extended by you and NRC management at all levels. We look forward to continuing our work with you and the entire NRC staff as we address the opportunities and challenges facing the Agency.

Sincerely,

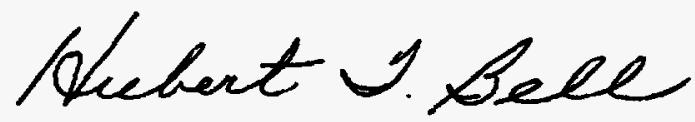

Hubert T. Bell

Inspector General 


\section{DISCLAIMER}

This report was prepared as an account of work sponsored by an agency of the United States Government. Neither the United States Government nor any agency thereof, nor any of their employees, makes any wartanty, express or implied, or assumes any legal liability or responsibility for the accuracy, completeness, or usefulness of any information, apparatus, product, or process disclosed, or represents that its use would not infringe privately owned rights. Reference herein to any specific commercial product, process, or service by trade name, trademark, manufacturer, or otherwise does not necessarily constitute or imply its endorsement, recommendation, or favoring by the United States Government or any agency thereof. The views and opinions of authors expressed herein do not necessarily state or reflect those of the United States Government or any agency thereof. 


\section{DISCLAIMER}

Portions of this document may be illegible electronic image products. Images are produced from the best available original document. 


\section{TABLE OF CONTENTS}

Reporting Requirements Index. iv

Executive Summary .$v$

The U.S. Nuclear Regulatory Commission ............................................... 1

Office of the Inspector General ................................................................ 3

The Audit Program .............................................................................................. 5

Audit Summaries ........................................................................... 5

Audits in Progress ........................................................................ 10

Significant Recommendations Not Yet Completed ........................ 13

The Investigative Program ....................................................................... 15

Investigative Case Summaries .................................................. 15

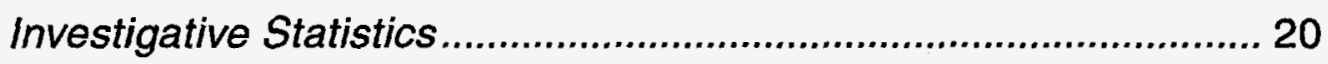

Special Feature................................................................................................... 22

Other Activities........................................................................................ 26

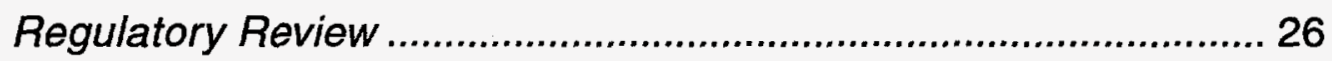

OIG Information and Planning Conference .................................. 28

Appendices

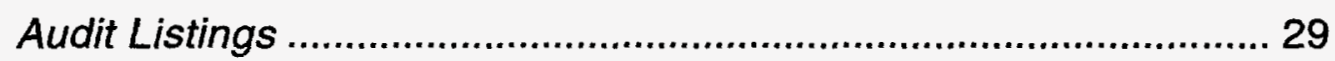

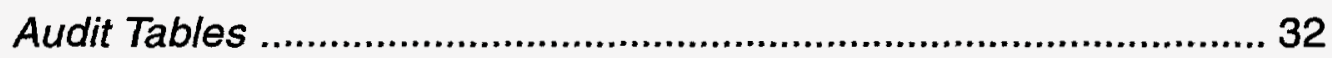

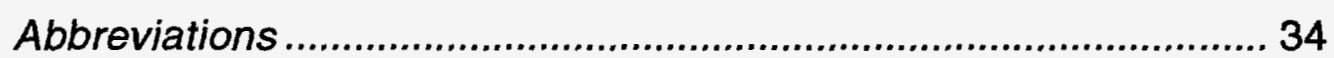

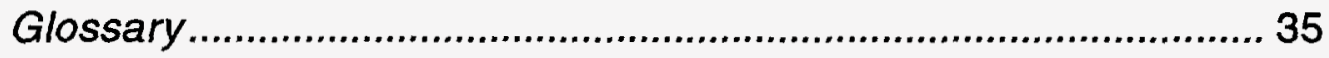




\section{REPORTING REQUIREMENTS INDEX}

The Inspector General Act of 1978, as amended (1988), specifies reporting requirements for semiannual reports. The requirements are listed and indexed to their applicable pages.

CITATION

Section 4(a)(2)

Section 5(a)(1)

Section 5(a)(2)

Section 5(a)(3)

Section 5(a)(4)

Section 5(a)(5)

Section 5(a)(6)

Section 5(a)(7)

Section 5(a)(8)

Section 5(a)(9)

Section 5(a)(10)

Section 5(a)(11) Significant Revised Management Decisions. None

Section 5(a)(12) Significant Management Decisions With Which OIG Disagreed ...... None 


\section{EXECUTIVE SUMMARY}

The following two sections highlight selected audits and investigations completed during this reporting period. More detailed summaries appear in subsequent sections of this report.

\section{AUDITS}

- The NRC initiated a number of actions to address regulatory weaknesses. The OIG found that some of these actions may not produce a safety benefit commensurate with their cost. The OIG also found that meanings of several important regulatory terms are unclear to many NRC and licensee staff. The OIG believes a comprehensive, integrated plan could help focus agency resources on those issues with the most safety significance, and that a focus on plant safety will enhance the NRC's credibility as an effective regulator.

- Because of its wide-ranging potential impact, the OIG has been tracking the Year 2000 issue for some time. The OIG found that success of the NRC's Year 2000 program can be enhanced by:

- issuing a policy directive

- establishing and communicating the NRC's responsibilities with respect to licensees' actions to address Year 2000 problems

- ensuring that managers consider the impact of Year 2000 problems when assessing program risk. 
In response to a memorandum from the NRC Chairman, the Acting Chief Financial Officer proposed an approach to developing an agencywide, integrated financial management system. The OIG initiated an evaluation to identify and gain an understanding of the best practices for developing such a system, and found that successful projects typically include:

- ensuring top level commitment and involvement

- learning from the experiences of others

- minimizing software modifications

- establishing realistic milestones and cost estimates.

Because this system will have agency-wide financial management implications, the OIG will continue to monitor its development and implementation.

The NRC sponsors a Federally Funded Research and Development Center (FFRDC) called the Center for Nuclear Waste Regulatory Analyses, which provides the NRC with long-term technical assistance and research related to the High-Level Waste program. The Federal Acquisition Regulation (FAR) requires that, prior to extending the contract for an FFRDC, sponsors conduct a comprehensive review of their use and need. The OIG found that the draft renewal justification assesses some, but not all, of the FAR considerations. 


\title{
INVESTIGATIONS
}

The OIG obtained information that a number of NRC employees accepted a dinner that was paid for by several top companies in the nuclear industry. Upon investigating the incident, the OIG determined that several NRC employees attended social events during a conference sponsored by nuclear vendors, which violated Federal ethics regulations pertaining to the unauthorized acceptance of gifts.

\begin{abstract}
The OIG investigated an NRC contractor for a potential organizational conflict of interest and determined that the contractor violated the "work for others" clause in its contract with the NRC by performing similar work for a corporation. The OIG also determined that an official of the contractor made a false statement when he signed the organizational conflict of interest certification in a proposal for a task order under the NRC contract. The matter was referred to the Department of Justice and prosecution was declined.
\end{abstract}

The OIG investigated a number of allegations related to an NRC-led Independent Safety Assessment (ISA) of the Maine Yankee Atomic Power Station. These allegations called into question certain actions taken by the Governor of Maine and NRC staff members regarding the handling of the ISA and their interactions with the public-at-large. The OIG found no evidence of individual wrongdoing or inappropriate actions by NRC officials. However, the OIG determined that the public was afforded insufficient time to review the ISA findings prior to a scheduled public meeting to discuss them. 
The OIG received an allegation that an inspection of a security breach at the Millstone Nuclear Power Station conducted by the NRC's Region I office was inadequate. The OIG determined that Region I inspectors did not inquire into apparent problems with the Millstone security system, which may have contributed to an unauthorized access incident. The OIG also determined that an inspection report prepared by the NRC regarding the incident was misleading as to the work actually performed.

The OIG investigated an NRC employee for conducting a real estate business on government time. The OIG determined that the employee was a licensed broker whose business answering machine message referred callers to his NRC telephone number. The employee resigned from the government while administrative action by the NRC was pending.

The OIG investigated an NRC employee for possible misuse of an American Express government credit card. The OIG determined that the employee used the government credit card to make a number of unauthorized withdrawals from Automated Teller Machines (ATMs), including several from ATMs in Atlantic City, New Jersey. The employee was suspended without pay.

- Based on an inquiry by Congressman Newt Gingrich, the OIG conducted an investigation of the use of frequent flyer benefits by a number of former and current NRC executives. The OIG had previously investigated a number of the former executives for alleged frequent flyer abuse and found that two of them had accumulated substantial frequent flyer miles due to official government travel. The OIG did not develop any evidence that a current employee named in the Congressional inquiry had abused frequent flyer miles. 


\section{THE U.S. NUCLEAR REGULATORY COMMISSION}

The U.S. Nuclear Regulatory Commission (NRC) was established as an independent Federal agency by the Energy Reorganization Act of 1974, as amended. This act, along with the Atomic Energy Act of 1954, as amended, provides the framework for regulating the Nation's commercial nuclear power industry and use of nuclear materials.

The NRC's mission is to regulate the Nation's civilian use of byproduct, source, and special nuclear materials to ensure adequate protection of public health and safety, to promote the common defense and security, and to protect the environment. The NRC's scope of responsibility includes regulation of commercial nuclear power plants; research, test, and training reactors; fuel cycle facilities; medical, academic, and industrial uses of nuclear materials; and the transport, storage, and disposal of nuclear materials and waste.

The NRC adheres to the following Principles of Good Regulation:

- Independence - Nothing but the highest possible standards of ethical performance and professionalism should influence regulation.

- Openness - Nuclear regulation is the public's business, and it must be transacted publicly and candidly.

- Efficiency - The American taxpayer, the rate-paying consumer, and licensees are all entitled to the best possible management and administration of regulatory activities.

- Clarity - Regulations should be coherent, logical, and practical.

- Reliability - Regulations should be based on the best available knowledge from research and operational experience. 
The NRC's Fiscal Year 1997 (FY97) budget is approximately $\$ 476.8$ million, which includes the OIG's budget of $\$ 5$ million. The NRC is relatively unique among Federal agencies because it is required by the Omnibus Budget Reconciliation Act of 1990 to recover approximately 100 percent of its budget authority. Therefore, the agency must employ sound financial practices to fully comply with its legislative mandates. The OIG's financial audits help the agency

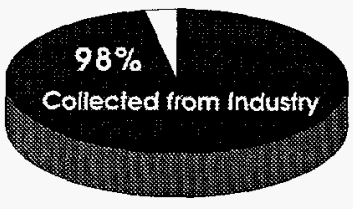

NRC FY96 Budget

The OIG's financial audits helped the agency meet its financial objectives. to meet these objectives. In FY96, the NRC was appropriated approximately $\$ 473$ million, of which $\$ 11$ million was derived from the Nuclear Waste Fund. Of the remaining $\$ 462$ million, the NRC collected $98 \%$ through fees and other charges.

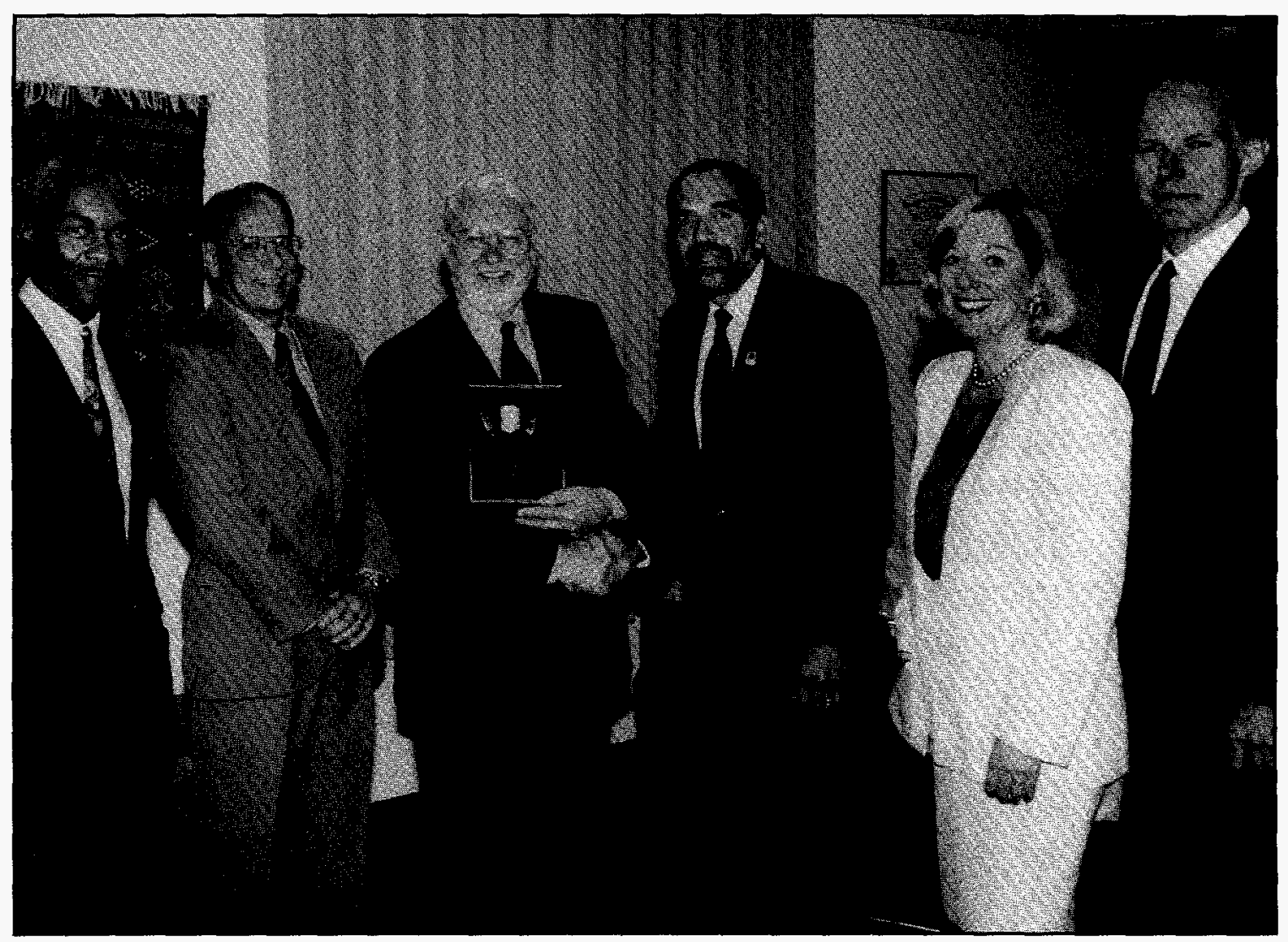

NRC Inspector General Hubert T. Bell and staff present a plaque to departing Commissioner Kenneth C. Rogers. 


\section{OFFICE OF INSPECTOR GENERAL}

The Inspector General Act of 1978 created independent and objective units in Federal agencies to:

- conduct and supervise audits and investigations relating to programs and operations

provide leadership and coordination, and recommend policies

for activities designed to:

- promote economy, efficiency, and effectiveness in the administration of programs and operations

- prevent and detect fraud and abuse in such programs and operations

- provide a means for keeping the head of the agency and Congress fully and currently informed about problems and deficiencies.

These units, called Offices of Inspector General (OIGs), are required to: perform comprehensive audits of programs, operations, grantees, and contractors of the agency

- conduct criminal, civil, and administrative investigations of those individuals and entities that may have engaged in fraud or otherwise violated laws and regulations designed to ensure and protect the government's programs, beneficiaries, and taxpayers.

The NRC OIG, established in 1988 by an amendment to the Inspector General Act, accomplishes its mission by performing audits, special evaluations, investigations, and event inquiries.

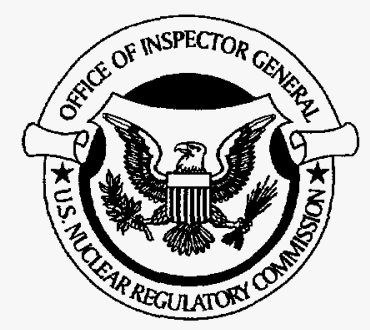

The OIG's audit staff conducts performance and financial audits, as well as special evaluations. Performance audits focus on NRC administrative and program operations. Financial audits review the NRC's internal control systems, transaction processing, and financial systems. The OIG conducts special evaluations to examine the implications of NRC programs that affect national issues. 
The OIG's investigative staff conducts investigations and event inquiries. The staff investigates violations of law or misconduct by NRC employees and contractors, and allegations of fraud, waste, or abuse affecting NRC programs and operations. An event inquiry is an investigative report documenting the examination of events or agency actions that do not focus specifically on individual misconduct. These reports identify institutional weaknesses that led to or allowed a problem to occur.

The Clinton Nuclear

Plant, where an

NRC team recently performed an inspection.

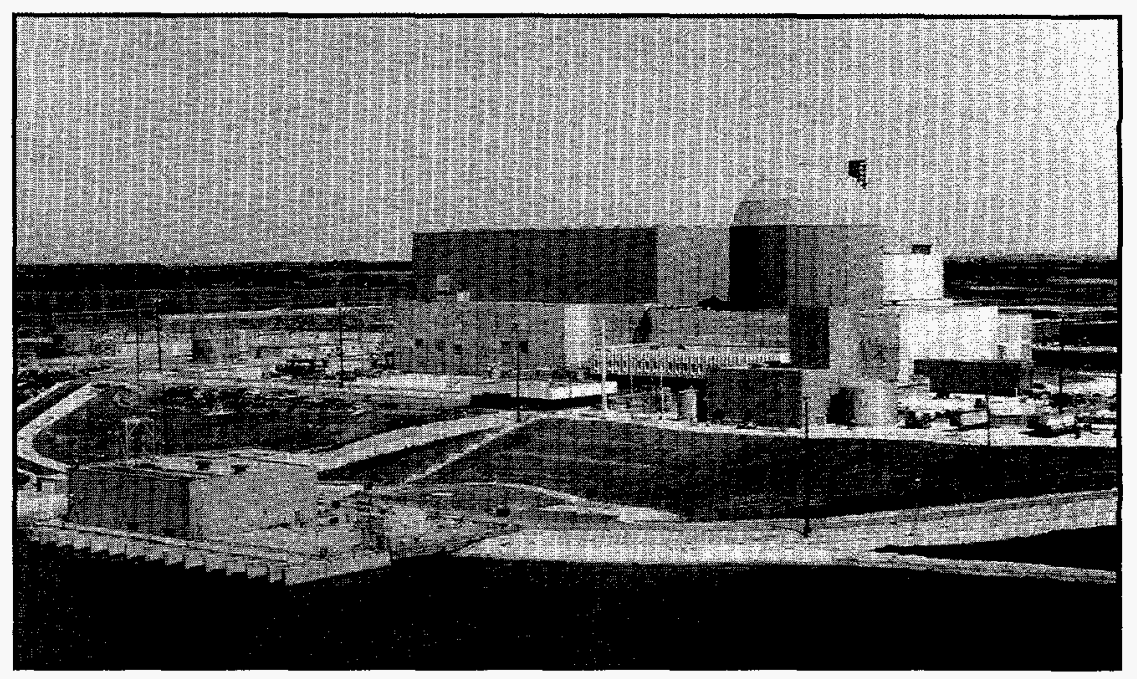

The OIG's Counsel reviews existing and proposed legislation, regulations, and policies to provide the NRC with a regulatory commentary that documents an objective analysis of vulnerabilities created within agency programs and operations. The intent of these reviews is to prospectively identify and assist the agency in preventing problems.

The OIG shares in the NRC's responsibility to provide adequate assurance to the public for the protection of its health and safety in the commercial use of nuclear materials and in the operation of nuclear facilities. The OIG assists the agency by assessing and reporting on the NRC's efforts to ensure that its safety-related programs are operating effectively.

Of additional importance is the NRC's responsibility for ensuring that individuals who identify nuclear safety concerns regarding the use of nuclear materials do not suffer adverse job actions as a result of reporting these concerns. The OIG continually evaluates the NRC's efforts to combat this type of unlawful discrimination. 


\section{THE AUDIT PROGRAM}

To help the agency improve its effectiveness, the OIG completed 5 performance and financial audits, 2 special evaluations, and analyzed 21 contract audit reports issued by the Defense Contract Audit Agency (DCAA). The audits and special evaluations resulted in 11 recommendations and suggestions to NRC managers.

\section{AUDIT SUMMARIES}

\section{The NRC Needs a Comprehensive Plan to Resolve Regulatory Issues}

In 1993, the NRC became aware of engineering practices by a licensee that were outside the design basis of the plant and a violation of its operating license. In response, the agency conducted inspections and reviews that identified numerous other issues of concern regarding licensed activities and regulatory compliance. In 1995, the NRC received allegations of improprieties at another nuclear plant while it was shut down for refueling. The OIG also found that the meaning of important regulatory terms are unclear to many NRC and licensee staff. Prompted by these events, issues identified in related OIG reports, and other internal reviews, the NRC initiated a number of actions to address regulatory weaknesses.

The NRC has taken a number of actions, and has plans for more, related to enforcing strict compliance with regulatory requirements that have large resource costs to both the agency and the industry. The OIG found that some of these actions may not produce a safety benefit commensurate with their cost to the agency to enforce, and to the industry to implement.

The OIG believes that the NRC needs to recognize that the cost to verify compliance with regulatory requirements may not produce commensurate safety benefits. The OIG issued an audit report that recommended that the agency establish a comprehensive, integrated plan to resolve regulatory issues which could be used to 
guide the agency in focusing resources on those issues with the most safety significance. The report also suggested that, as part of this plan, the NRC needs to clearly articulate how it will meet its goal of moving to a risk-informed, performance-based regulatory system while maintaining regulatory standards. The OIG believes that a focus on plant safety will enhance the NRC's credibility as an effective regulator.

\section{Special Evaluation: The NRC's Progress on the Year 2000 Issue}

The Year 2000 problem has gained enormous attention in the information systems world because it involves the method that dates are recorded and utilized in many computer systems and a variety of other devices such as security systems, elevators, and phone systems. Due to its wide-ranging potential impact and recent emphasis from other Federal agencies, the OIG has been tracking this issue for some time.

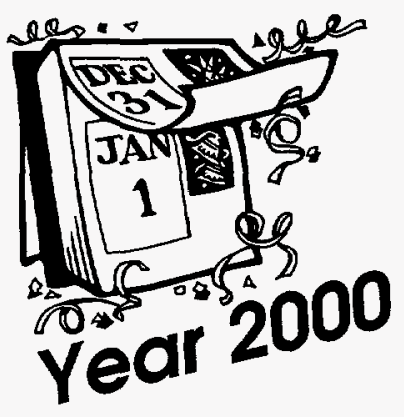

The OIG provided a briefing to the NRC Chief Information Officer and other senior managers on this topic and issued a Special Evaluation Report containing several suggestions for facilitating the agency's Year 2000 efforts. For example, the report stated that the NRC can provide greater assurance that its Year 2000 program will be successful by:

issuing a policy directive in support of the program

- establishing and communicating a position on the extent of the NRC's regulatory responsibilities with respect to licensees' actions to address Year 2000 problems

ensuring that managers consider the potential impact of Year 2000 problems when assessing program risk as part of their Federal Managers' Financial Integrity Act requirements, and account for Year 2000 issues in their management control plans and reasonable assurance statements. 


\section{Review of the NRC's Implementation of the Federal Managers' Financial Integrity Act for Fiscal Year 1996}

The Federal Managers' Financial Integrity Act (FMFIA) requires Federal managers to establish a continuous process for evaluating, improving, and reporting on the internal controls and accounting systems for which they are responsible. The FMFIA also requires submitting a report to the President and Congress on the status of the management controls and financial systems that protect the integrity of agency programs and administrative

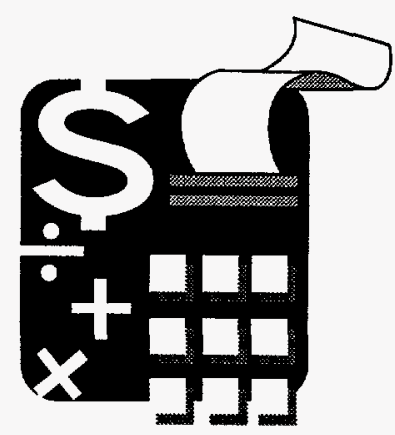
activities. To assist the NRC in evaluating its management control program, the OIG annually reviews the NRC's program.

Overall, the OIG found that the NRC has complied with the requirements of the FMFIA during FY96. Although the OIG's work did not identify any material weaknesses in FY96, the former Executive Director for Operations identified the adequacy of the NRC's program to ensure licensees' compliance with certain regulatory requirements as a potential material weakness. The NRC preliminarily determined that the concern was not a material weakness; however, the agency is evaluating the need for additional action. The OIG advised the NRC that it will continue monitoring the agency's actions on this issue.

\section{Review of the NRC's Draft Renewal Justification to Continue the Federally Funded Research and Development Center}

Since October 1987, the NRC has sponsored a Federally Funded Research and Development Center (FFRDC), called the Center for Nuclear Waste Regulatory Analyses (the Center). The Center provides the NRC with long-term technical assistance and research related to the High-Level Waste (HLW) program under the Nuclear Waste Policy Act of 1982, as amended. The Federal Acquisition Regulation (FAR) requires that, prior to extending the contract for an FFRDC, sponsors conduct a comprehensive review of the use of and need for their FFRDCs. 
NRC staff developed an interim plan for performing its FFRDC renewal justification, implemented that plan, and drafted a renewal justification. The OIG reviewed the NRC's draft renewal justification and found it did not provide the Commission with sufficient information on which to make its judgment because:
- assumptions used by the staff in drawing conclusions were not identified
- an Office of the Controller cost comparison referenced by the staff did not reflect the current environment affecting the HLW program.

The OIG made a recommendation in its report to address the issues identified.

\section{Review of M-Cubed's Work on the Reactor Program System}

The OIG previously reported on contract management problems regarding the M-Cubed Information Systems, Inc. contract, and identified lessons the agency could learn to more effectively develop systems and oversee contracts. Because of continuing concerns about the M-Cubed contract, the OIG initiated a further review of M-Cubed's work on the inspection planning module of the Reactor Program System (RPS).

The OIG found that the agency's best interests were not served in continuing work on the RPS using M-Cubed as a subcontractor to Applied Management Systems, Inc. (AMS). NRC managers expected that the agency would benefit from AMS' oversight; however, little, if any, benefit was gained. As a result, agency resources were not effectively managed, and the NRC incurred an additional cost in the form of the fee paid to AMS. To improve the NRC's management of contracts for developing agency systems and more effectively serve the agency's interests, the OIG report recommends that the various NRC offices reach better agreement and coordination in determining how to best serve NRC's interests. 


\section{Evaluation of Best Practices for Developing and Implementing an Integrated Financial Management System}

In a February 1997 memorandum, the NRC Chairman directed the Acting Chief Financial Officer to develop a plan for establishing an agency-wide financiál management system. The Chairman stated that the new system should:

- be operational within the next two years

- be designed to integrate financial planning data with performance data

- have the goal of eliminating the need for multiple financial tracking systems.

In response, the Acting Chief Financial Officer proposed an approach to developing an integrated financial management system.

Due to the importance of this project and the NRC's past difficulties in developing management information systems, the OIG initiated an evaluation to gain an understanding of the best practices for developing such a system. The OIG provided a briefing to senior agency managers on the results of the evaluation, and issued a Special Evaluation Report that identified several factors that contribute to project success, including:

- ensuring top level commitment and involvement

- learning from the experiences of others

- minimizing software modifications

- establishing realistic milestones and cost estimates.

Because this system will have agency-wide financial management implications, the OIG will continue to monitor its development and implementation. 


\section{Review of NRC's Management Directive 6.1}

The Office of Management and Budget Circular A-50, "Audit Follow-up," requires each agency to establish systems to assure the prompt and proper resolution and implementation of audit recommendations. These systems should provide for a complete record of actions taken on all recommendations. The OIG reviewed the adequacy of the NRC's current directive for responding to OIG audit reports and for reaching resolution on recommendations.

Although the agency maintains a centralized tracking system, the OIG found that, due to recent organizational changes made by the Commission, Management Directive 6.1 needed updating. Accordingly, the OIG recommended that it be revised to identify the NRC officials responsible for reviewing and responding to OIG draft audit reports, and resolving disagreements on audit recommendations that arise between the OIG and agency officials.

\section{AUDITS IN PROGRESS}

\section{Survey of NRC/EPA Issues Regarding Radiation Standards}

In 1994, Congress directed the NRC and the Environmental Protection Agency to develop a plan to address the inconsistencies, gaps, and overlaps in current Federal radiation protection standards. The objective of this OIG survey is to determine the progress the two agencies have made in responding to congressional requests for agencies to establish consistent radiation standards for decommissioning activities. 


\section{Survey of the NRC's Work Force}

The OIG initiated a Special Evaluation to assess the current safety culture and climate of the agency's work force. The OIG is currently working with an independent contractor experienced in measuring organizational cultures and climates to develop a methodology to complete this survey.

\section{Survey of the NRC's Oversight of Gaseous Diffusion Plants}

The NRC recently assumed regulatory responsibility for two gaseous diffusion plants located near Piketon, Ohio and Paducah, Kentucky. These facilities prepare uranium so that it can be used as fuel in nuclear power reactors.

The objective of an OIG survey of these plants is to gain an understanding of the NRC's processes and management controls for regulating the plants, and the agency's working relationships with other Federal agencies involved.

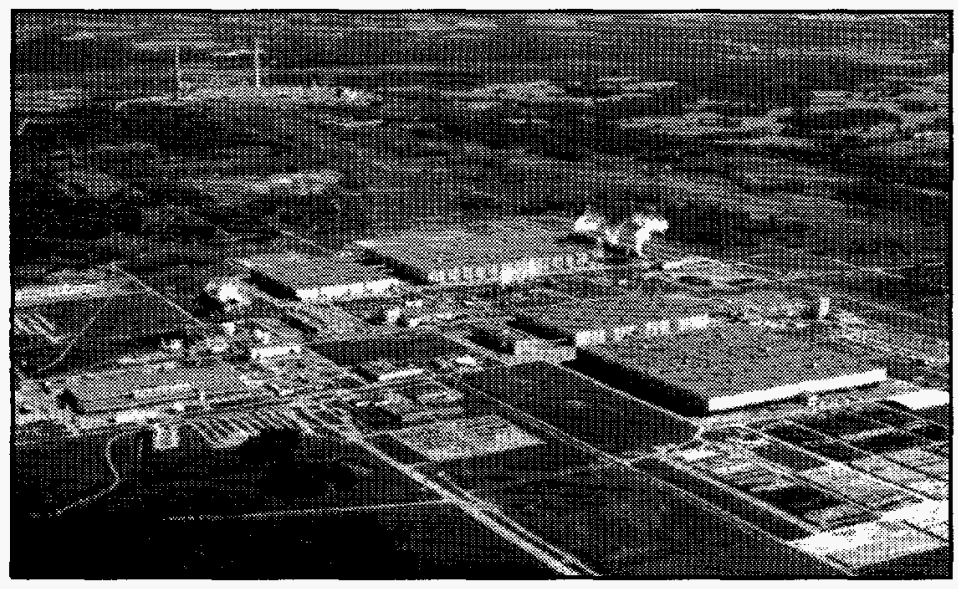

The Paducah, Kentucky Gaseous Diffusion Plant 


\section{Financial Statement Audit}

The Chief Financial Officers Act of 1990 requires that the NRC issue audited financial statements annually. The OIG's objective for this audit is to render an opinion on whether the FY97 financial statements fairly present the agency's financial position. The OIG also reports on NRC management's assertion about the effectiveness of internal controls, and NRC's compliance with applicable laws and regulations.

\section{Review of Project Manager Workload and NRR Processes}

The Office of Nuclear Reactor Regulation (NRR) has established a project manager function to assist in licensing and monitoring nuclear power plants. This audit examines the processes and guidance that the NRR has developed regarding tasks assigned to or involving project managers.

\section{Survey of the NRC's Administrative Activities}

The NRC performs a wide variety of administrative and information management activities in support of its mission. The objectives of this OIG survey are to determine the nature, reasons, and costs for the services and to identify areas for additional review. 


\section{SIGNIFICANT RECOMMENDATIONS NOT YET COMPLETED}

The Nuclear Waste Policy Act of 1982 requires that the NRC approve or disapprove the construction of a high-level waste repository within three to four years of receiving a Department of Energy (DOE) construction license application. To meet this deadline, the NRC enacted a rule requiring the development of an electronic information management system (or the Licensing Support System) to reduce the time needed for discovery during the license hearing process. The rule requires that the DOE design and develop the system, and that the NRC operate and maintain it.

In March 1995, the OIG issued a report entitled, NRC Needs to Provide Strong Direction for the Licensing Support System (LSS), which stated that the program had stalled over the past five years. Many delays were attributed to an inadequate system definition and disagreement between the DOE and the NRC regarding the roles and responsibilities of each agency. As a result, the OIG recommended that the NRC obtain a formal commitment from the DOE in an interagency agreement or Memorandum of Understanding (MOU) on key aspects of the LSS. In response, the Executive Director for Operations (EDO) appointed a Senior Management Team (SMT) to reevaluate the purpose and need for the LSS and to address the issues raised by the OIG audit.

In status reports issued in 1996, the EDO advised the Commission that the SMT would develop an action plan addressing the issues affecting the LSS program. However, due to Congressional budget action related to the DOE's high-level nuclear waste program, there was no resumption of any LSS activities and the DOE's LSSrelated activities remained stalled, including the finalization of an MOU with the NRC. The EDO also provided an SMT action plan to address outstanding LSS issues, which subsequently was revised to reevaluate the need for an LSS as originally envisioned.

This reevaluation has been ongoing since November 1996. The SMT recommended an option that it believes "provides the best solution for maintaining the basic functionality of the LSS conceptual design, while most flexibly accommodating current and future technological developments." 
To bring about the SMT's recommended changes to the LSS, a revised rule is required. As such, in July 1997, the SMT provided a proposed revised rule to the Commission for approval. The proposed revised rule eliminates the current prescriptive requirement in the existing rule for a centralized LSS administered by the NRC. As such, it also eliminates the requirement for an LSS Administrator. The proposed rule also requires that all potential parties, including the NRC and the DOE, must make their documentary material available in electronic form to all other participants beginning in the pre-application phase.

In September 1997, the Commission approved the revised rule with comments and directed the SMT to incorporate the comments and submit the proposed rule for publication in the Federal Register and for public comment. If this rule is adopted, the OIG will close out this audit recommendation. 


\section{THE INVESTIGATIVE PROGRAM}

During this reporting period, the OIG received 247 allegations, initiated 49 investigations and 5 event inquiries, and closed 30 cases and 4 event inquiries. In addition, 52 referrals were made to NRC management.

\section{INVESTIGATIVE CASE SUMMARIES}

\section{Improper Acceptance of Gratuity}

The Hartford Courant ran a story in December 1996 indicating that a number of NRC employees attended a conference at a Florida beach resort sponsored by the American Nuclear Society (ANS). The newspaper article further indicated that several NRC employees at the Conference accepted a dinner that was paid for by several top companies in the nuclear industry.

The OIG investigation disclosed that an NRC executive accepted free conference registration in exchange for his speaking and participation in the conference. The acceptance of free conference registration was permissible under 5 C.F.R. $\$ 2635.204(\mathrm{~g})(1)$ of the Federal ethics regulations as an item received incident to a speaking engagement. The executive's participation at the event could be viewed as a customary and necessary part of his performance as a senior NRC official, and his acceptance of free conference registration did not constitute a gift to him or to the agency.

The investigation further disclosed that three NRC employees, including the executive, attended one or more social events that were sponsored by nuclear industry vendors during the ANS conference. These gatherings were open to all ANS conference attendees and their guests. However, the NRC employees attended these events without seeking the requisite agency approval as set forth in NRC Management Directive (MD) 7.9, "Ethics, Approvals and Waivers." 
The NRC employees told the OIG that they were unaware of the agency's approval requirements contained in MD 7.9. They further stated that their supervisory chains, up to and including their office director, were aware of their possible attendance at the social events and did not advise them to request agency approval in accordance with MD 7.9. Because the market value of several of these events exceeded $\$ 20$, all three employees violated Federal ethics regulations pertaining to the unauthorized acceptance of gifts.

As a result of this investigation, the NRC's Office of the General Counsel has advised the OIG that ethics presentations to all employees will include scenarios such as those addressed in this case.

\section{Organizational Conflict of Interest}

The OIG received information that an NRC contractor, under contract to perform testing on industrial radiography devices, was simultaneously performing similar work for a private corporation. The OIG determined that the contractor violated the "work for other" clause in its contract with the government by performing similar work for the corporation while the NRC contract was still in effect.

The OIG also found that an official of the contractor made a false statement when he signed the organizational conflict of interest certification in the contractor's proposal for a task order under the NRC contract. The OIG determined that, at the time the official signed the certification, the contractor had ongoing related contracts with the private corporation. Further, the official did not inquire about the existence of any contracts that his company had that could have affected the accuracy of his certification to the NRC. The OIG referred the matter to the Department of Justice and prosecution was declined. 


\section{State of Maine Involvement with the NRC's Independent Safety Assessment (ISA) at Maine Yankee Atomic Power Station}

The OIG received allegations that the Governor of Maine appointed State members to an NRC-led Independent Safety Assessment Team (ISAT) to inappropriately influence an assessment of the Maine Yankee Atomic Power Station (MYAPS) and to obtain inside information on the NRC's assessment activities for the licensee. It was further alleged that the Citizen's Review Team (CRT) appointed by the Governor lacked the expertise to analyze the NRC's assessment activities.

Additionally, it was alleged that the NRC failed to adequately inform the public of the NRC's assessment findings and conclusions during a public meeting held after completion of the ISA. The alleger also questioned the accuracy of numerous public statements made by the Governor of Maine relating to the ISA, and suggested that NRC staff may have failed to provide the State with accurate information.

The OIG found no evidence that the ISAT findings or conclusions were inappropriately influenced by State of Maine ISAT members. Further, there was no indication that State of Maine representatives involved with the ISAT provided MYAPS personnel with information on the NRC's planned assessment activities. Additionally, the OIG found no evidence that NRC personnel provided State of Maine officials with inaccurate or misleading information relating to the ISA.

Although the OIG determined that the Governor's CRT lacked the technical expertise to analyze NRC's assessment activities, it was also determined that the CRT was not intended to provide the Governor with technical guidance. The CRT was appointed to assist the Governor in interpreting the NRC's assessment activities from different perspectives and to act as the Governor's "eyes and ears." The OIG concluded that, while NRC staff made efforts to advise members of the public of the ISAT findings prior to the public meeting, the public was nonetheless afforded insufficient time to review the report prior to the public meeting. 


\section{NRC Inspection Report Misleading as to Scope of Work Performed}

The OIG received an allegation that an inspection of a security breach at the Millstone Nuclear Power Station conducted by the NRC's Region I office was inadequate. The alleger claimed that two workers at the plant were fired for gaining unauthorized site access through a security turnstile. According to the alleger, the NRC failed to adequately review the incident and to address several serious lapses in the Millstone security system.

The OIG determined that Region I inspectors did not inquire into apparent problems with the Millstone security system that may have contributed to the unauthorized access incident. The OIG also determined that an NRC inspection report regarding the incident was misleading as to the work actually performed. Specifically, while a reading of the report gives the impression that NRC inspection activities resulted in the facts cited in the report, the OIG determined that there was no NRC inspection into this incident. The NRC inspection effort consisted only of documenting a telephone notification of the incident from the licensee, with no verification by Region I staff.

\section{Conducting a Real Estate Business on Government Time}

An NRC employee was investigated by the OIG for conducting a real estate business on government time. The OIG investigation determined that the employee was a licensed real estate broker and the sole owner and operator of a real estate business. The OIG further determined that a message on the employee's business answering machine referred callers to the employee's NRC telephone number. The OIG referred the matter to NRC management for consideration of administrative action, and the employee resigned from the government.

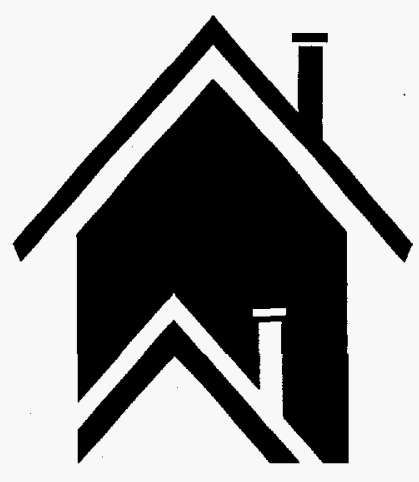




\section{Abuse of Government Credit Card}

The OIG received information that an NRC employee was using an American Express (AmEx) Government Credit Card to make unauthorized cash withdrawals from Automated Teller Machines (ATMs). The OIG investigation disclosed that the employee made a number of unauthorized cash withdrawals, including several from ATMs in Atlantic City, New Jersey.

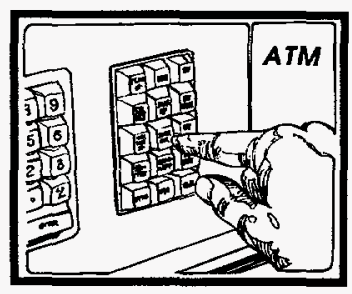

The OIG further determined that the employee provided inconsistent explanations to OIG, AmEx, and the NRC travel office regarding confusion between the employee's personal credit cards and the AmEx Government Credit Card. The OIG referred the matter to NRC management for consideration of administrative action, which resulted in the employee being suspended without pay.

\section{Misuse of Frequent Flyer Benefits}

Based on an inquiry from Congressman Newt Gingrich, the OIG conducted an investigation of the abuse of frequent flyer benefits by a number of former and current NRC executives. The OIG investigation determined that several of the former employees named in the Congressional inquiry were the subjects of previous OIG investigations into the alleged abuse of frequent flyer miles.

In one of the previous investigations, the OIG found that an individual arranged official government trips to coincide with personal business and failed to account for promotional airline mileage credits gained through official travel. In another earlier investigation involving a former employee, it was determined that the individual accumulated a substantial number of frequent flyer miles as a result of official travel; however, the employee never converted the frequent flyer miles to personal use. The OIG subsequently contacted this employee, who agreed not to convert the frequent flyer miles to personal use in the future.

The current OIG investigation revealed that the employee who is still with the NRC and named in the Congressional inquiry had not accrued sufficient frequent flyer miles from official travel to take advantage of frequent flyer program benefits. 


\section{INVESTIGATIVE STATISTICS}

\section{Source of Allegations - April 1, 1997 through September 30, 1997}

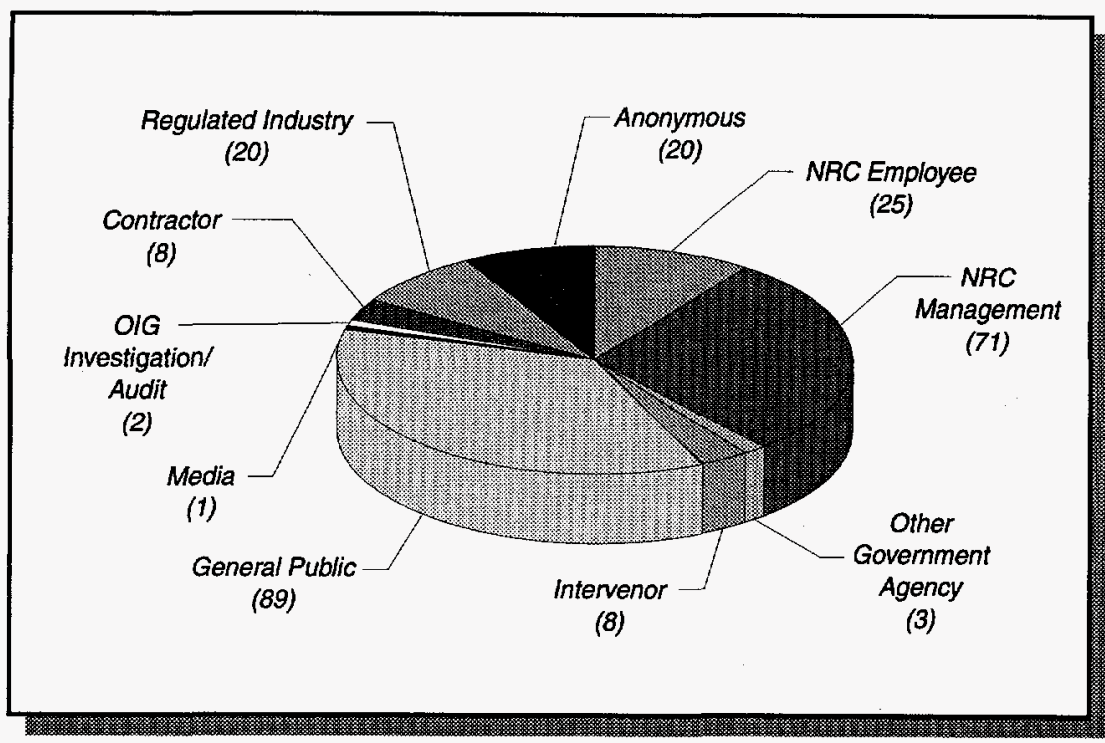

Of the 247 total allegations, none were carried forward from the previous period, and 31 resulted from hotline calls.

Disposition of Allegations - April 1, 1997 through September 30, 1997

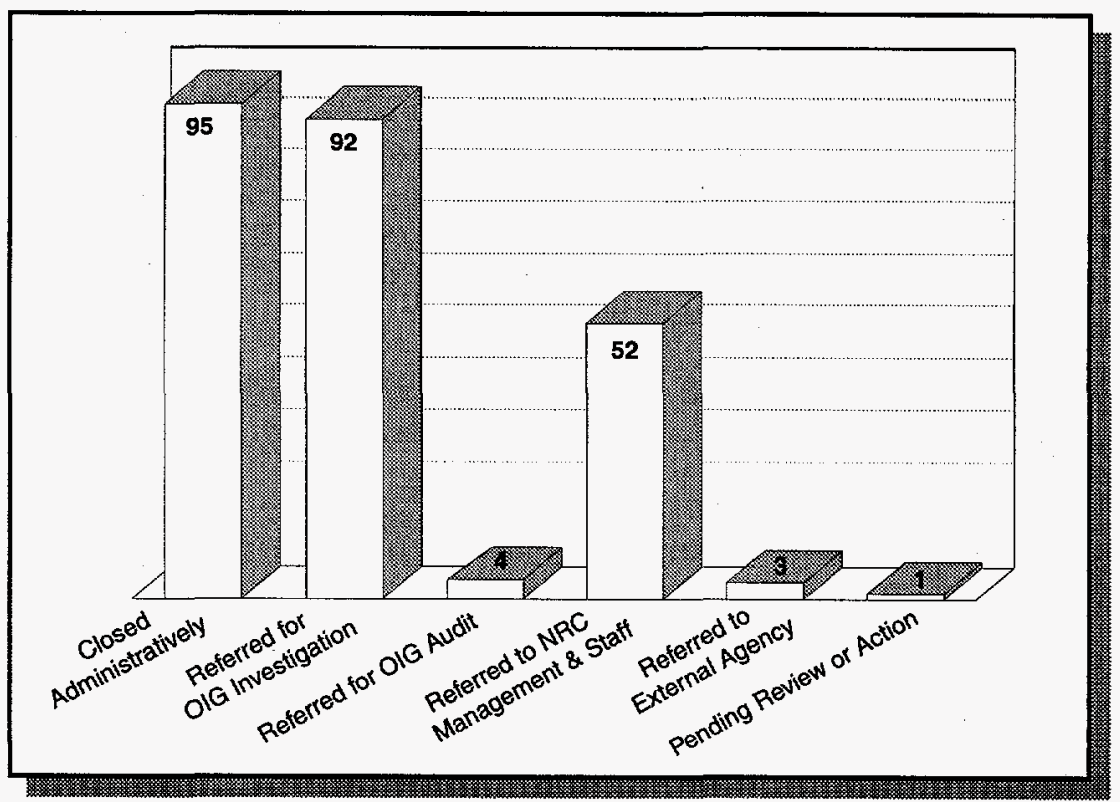




\section{Status of Investigations}

DOJ Referrals

Pending DOJ Action

DOJ Declinations

Indictments and Arrests

6

Convictions

PFCRA Referrals

PFCRA Recoveries

$\$ 14,100$

Other Recoveries

NRC Administrative Actions:

Terminations and Resignations

Suspensions and Demotions

Other Administrative Actions

\section{Investigations Summary}

\begin{tabular}{|lcccc|}
\hline Classification of Investigations & Carryover & Opened & Closed & In Progress \\
Conflict of Interest & 7 & 3 & 4 & 6 \\
Internal Fraud & 3 & 2 & 1 & 4 \\
External Fraud & 5 & 3 & 4 & 4 \\
False Statements & 1 & 5 & 1 & 5 \\
Theft & 2 & 2 & 2 & 2 \\
Misuse of Government Property & 2 & 4 & 4 & 2 \\
Employee Misconduct & 8 & 13 & 8 & 13 \\
Management Misconduct & 6 & 12 & 3 & 15 \\
Technical Allegations - Other & 7 & 3 & 3 & 7 \\
Whistleblower Reprisal & 2 & 2 & 0 & 4 \\
Total Investigations & 43 & 49 & 30 & 62 \\
Total Event Inquiries & 4 & 5 & 4 & 5 \\
\hline
\end{tabular}




\section{SPECIAL FEATURE}

\section{OIG OUTREACH — IN PERSON AND IN PRINT}

The Inspector General Act, 5 U.S.C. Section 4(a)(3), directs the Inspector General (IG) to conduct, supervise, and coordinate activities to promote economy and efficiency, and to prevent fraud and abuse in agency programs and operations. To proactively pursue the elimination of fraud and abuse within the agency, Hubert T. Bell, the NRC IG, embarked on three major initiatives during the last year.

- Initiative 1: Regional Training

The IG and his senior staff (David C. Lee, Deputy IG; Thomas J. Barchi, Assistant Inspector General for Audits (AIGA); James E. Childs, Assistant Inspector General for Investigations (AIGI); and Maryann L. Grodin, Counsel) traveled to each of the four Regional Offices and the Walnut Creek Field Office.

The primary goals of the presentations were to educate employees to enable them to avoid violations and to encourage communication between the OIG and regional personnel. To assure that the presentations were responsive to employee concerns, the OIG contacted regional administrators in advance and queried them as to areas

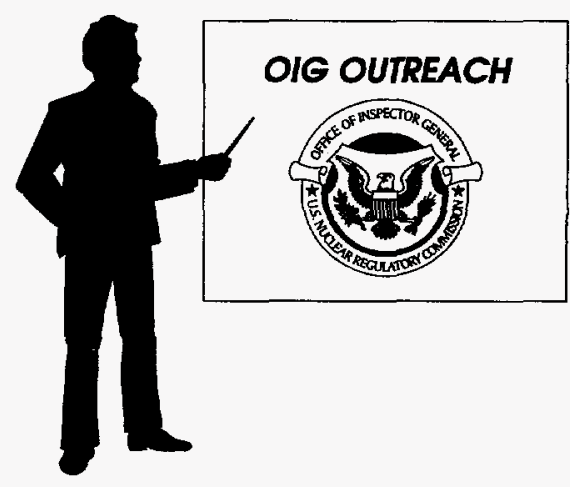
of interest and potential questions.

Opening remarks by Inspector General Bell described the structure of the office and introduced the OIG's senior managers and their areas of responsibility. He then identified several new or revised policies and procedures within the OIG. His presentation emphasized individual responsibility in making allegations and also detailed the OIG's criteria and documentation for issuing "clearance letters." 
Presentations by the OIG senior staff followed the IG's remarks. The AIGA described the audit process and highlighted findings from recent audits. The AIGI delineated investigative procedures, summarized closed investigations and their results, and provided statistics on allegations, convictions, and adverse actions. The OIG Legal Counsel explained the independence of the IG counsel, the regulatory review function, and limitations imposed on dissemination of OIG documents.

Each of the regional meetings concluded with an extended, lively question and answer session. Feedback from OIG senior staff and regional NRC employees alike have indicated that these meetings resulted in greater appreciation for the mission requirements of the IG and agency offices.

\section{Initiative II: Third Edition of "The IG at the NRC"}

In 1991, the OIG published the first edition of "The IG at the NRC," an informational reference booklet designed to introduce agency employees to the newly created IG office. This document described the OIG's mission and functions; detailed employee rights and warnings in investigations; identified and distinguished investigations, audits, and regulatory reviews; and contained excerpts from the Inspector General Act. In 1995, a second edition was published to reflect newly developed and formalized policies and procedures. Built on the structure of the first, the revised edition emphasized the agency employee's role in furthering the mission of the OIG and their responsibility to report wrongdoing. It also provided definitions for each OIG document product.

Recognizing the changing focus of government and the IG community, and prompted by the Government Performance and Results Act, Inspector General Bell's organizational orientation has evolved to be more centered on planning, budget, and performance. These innovations, accompanied by modifications in the office organization and other policy changes, resulted in the need for an updated edition of "The IG at the NRC." 
Scheduled for printing in early FY98, the booklet's third edition will reflect the new organizational structure, underscore the responsibility inherent in lodging allegations, document the revised clearance letter policy, elaborate on employee rights and warnings, and detail the IG's authority to withhold documents.

In addition to serving as a reference for IG personnel, the "IG at the NRC" is given to each new agency employee at orientation, and is widely distributed to the public, industry, and licensees.

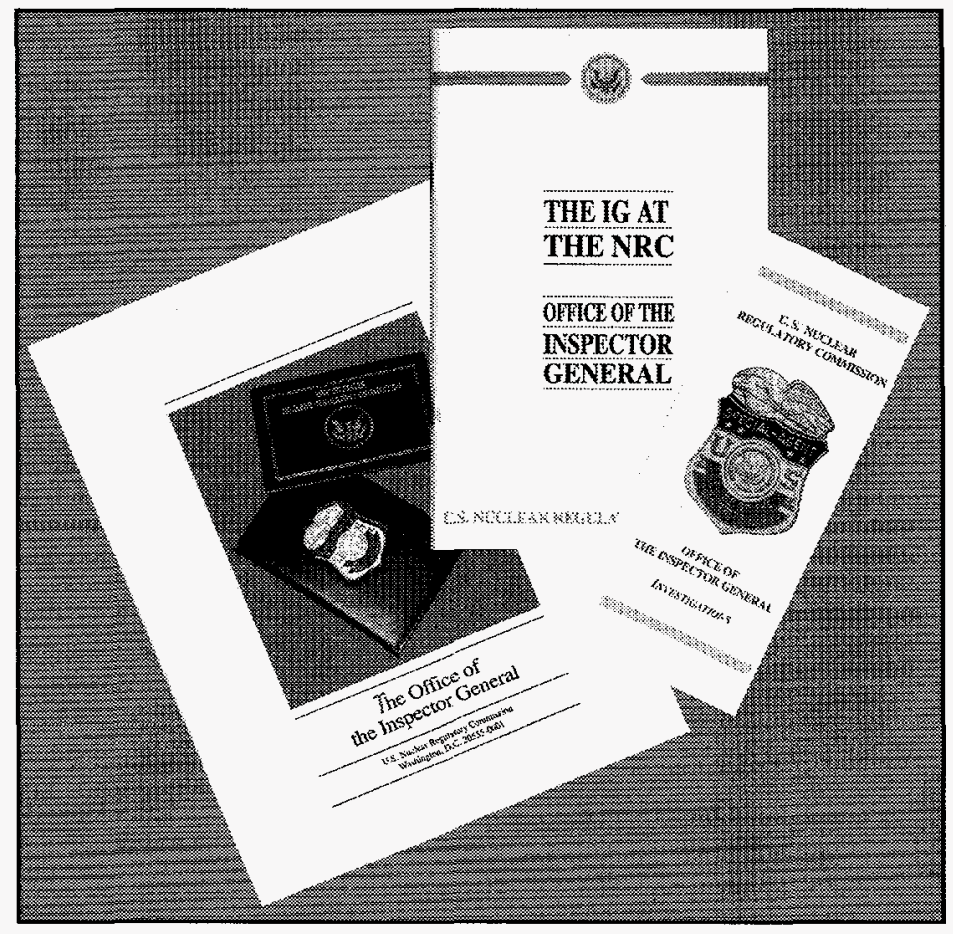

The OIG recently enhanced its public outreach program with new and revised publications. 


\section{Initiative III: New OIG Brochure and Investigative Pamphlet}

"The IG at the NRC" booklet serves as a basic reference and source of comprehensive information about the OIG. However, the OIG also recognized needs for a publication more suitable for use in less formal settings, and for a guide featuring the investigative function of the OIG. These needs were met with the creation of two new documents:

- The OIG Brochure is a magazine-like abstract of the OIG organization, with photos of personnel performing in their respective roles as investigators, auditors, and administrators. It is used in training and in coordinating activities within the Federal IG community.

- The Investigative Pamphlet is a tri-fold leaflet summarizing the OIG's investigative mission and activities. Designed to augment the liaison efforts among investigative offices, the pamphlet has enhanced communication and cooperation with other law enforcement agencies.

The three initiatives described above have served to enhance the effectiveness of the OIG in combating fraud and abuse by fostering an environment of openness and instilling confidence in the integrity of the OIG's people and processes. 


\section{OTHER ACTIVITIES}

\section{REGULATORY REVIEW}

The Inspector General Act, 5 U.S.C. App 3, Section 4(a)(2), requires the OIG to review existing and proposed legislation and regulations, and to make recommendations concerning the impact of such legislation or regulations on the economy and efficiency of programs and operations administered by the agency.

From April 1, 1997, through September 30, 1997, the OIG reviewed more than 200 agency documents, including approximately 80 documents issued by the Office of the Secretary (SECYs) and 150 Federal Register Notices, regulatory actions, and statutes.

Regulatory Commentaries were provided on fraud, waste, and abuse issues to focus agency managers on the importance of considering aspects of policy and procedures that can be related to fraud, waste, and abuse prevention. The OIG initiated dialogue with the agency on several policy concerns, and collegial efforts resulted in improved guidance to the agency staff in other areas. Commentaries raising the most significant issues are summarized below.

Two of the commentaries discussed issues related to the protection and distribution of OIG documents. The first addressed document distribution under draft Management Directive 3.4, "Release of Information to the Public." The comments on this document provided a background and conclusion to an ongoing discussion with regard to treatment of OIG documents within the agency. In response to questions raised by the agency staff, the Assistant for Operations for the Executive Director for Operations issued a memorandum describing the protection to be afforded OIG documents. Subsequently, issues regarding proper disposal of OIG documents residing in agency program files were raised and resolved. Finally, in response to the OIG request in the commentary, the agency agreed to provide periodic announcements to safeguard OIG documents. 
The second commentary related to OIG documents involving the draft Proposed Rule Amending 10 Code of Federal Regulations Part 9, Subpart A, the Freedom of Information Act (FOIA). In addition to addressing concerns regarding compliance with the Electronic Freedom of Information Act Amendments of 1996, the comments clarified the OIG's internal FOIA processing procedures and denial authority. In both instances, revisions were made to the draft documents after collegial discussion and agreement.

The OIG comments on a proposed NRC Inspection Manual chapter, called "Communication Protocol for Assessing Offsite Emergency Preparedness Following a Natural Disaster," expressed concern that the directions pertaining to restart authority needed clarification.

Another comment, regarding NUREG-0544, Rev. 4, "NRC's Collection of Abbreviations," emphasized the need for clarity. The OIG noted that there could be potential safety significance to having several identical abbreviations stand for very different meanings. The OIG included a suggestion that numbers could be added to the abbreviation letter symbols to avoid confusion. 


\section{OIG INFORMATION AND PLANNING CONFERENCE}

On September 10, 1997, the sixth Annual OIG Information and Planning Conference was held at NRC Headquarters in Rockville, Maryland. The purpose of the conference was to assist the OIG in developing its work plan for FY98. The conference theme was "New Directions in Regulatory Effectiveness." The keynote speaker, Commissioner Nils J. Diaz, and the NRC's newly formed Executive Council addressed how the OIG could be of greater assistance to the agency.

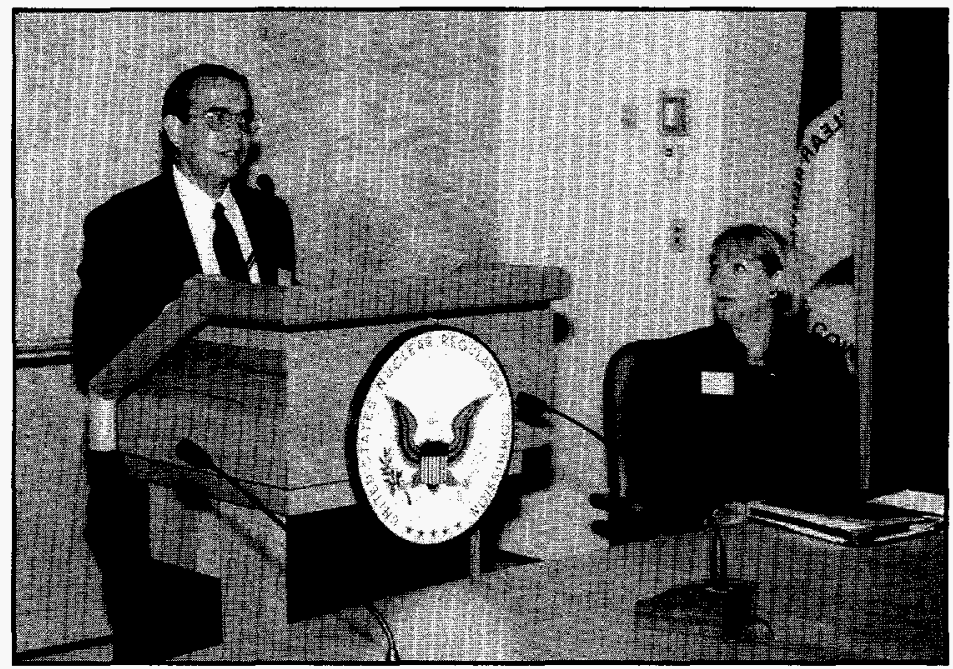

Commissioner Nils J. Diaz addresses participants at the Annual OIG Information and Planning Conference, as OIG's Counsel, Maryann Grodin, looks on.

The balance of the agenda included several speakers and panels from the NRC, industry, and other agencies. Topics addressed included:

Issues and Initiatives - The Congressional Scene

- Status and Issues - Proposed Regulation of DOE Activities

Deregulation of the Energy Industry

Best Practices to Increase the Effectiveness and Efficiency of IGs.

Following each presentation, the speakers entertained questions from the audience. 


\section{APPENDICES}

\section{AUDIT LISTINGS}

Internal Program Audit and Special Evaluation Reports

\begin{tabular}{lll}
\hline Date & Title & Number \\
\hline $03 / 31 / 97$ & $\begin{array}{l}\text { Review of NRC's Implementation of the } \\
\text { Federal Managers' Financial Integrity Act } \\
\text { for Fiscal Year 1996 }\end{array}$ & OIG/96A-17 \\
$04 / 23 / 97$ & $\begin{array}{l}\text { Review of M-Cubed's Work } \\
\text { on the Reactor Program System }\end{array}$ & OIG/97A-02 \\
$06 / 09 / 97$ & $\begin{array}{l}\text { Evaluation of Best Practices for Developing } \\
\text { and Implementing Integrated Financial } \\
\text { Management System }\end{array}$ & \\
$06 / 26 / 97$ & $\begin{array}{l}\text { Special Evaluation: NRC's Progress on } \\
\text { the Year 2000 Issue }\end{array}$ & OIG/97E-10 \\
$07 / 11 / 97$ & $\begin{array}{l}\text { Review of NRC's Draft Renewal Justification } \\
\text { to Continue the Federally Funded Research } \\
\text { and Development Center }\end{array}$ & OIG/97E-13 \\
$08 / 21 / 97$ & $\begin{array}{l}\text { NRC Needs Comprehensive Plan } \\
\text { to Resolve Regulatory Issues }\end{array}$ & OIG/97A-07 \\
$09 / 05 / 97$ & $\begin{array}{l}\text { Review of NRC's Management Directive 6.1 } \\
\text { Ren-01 }\end{array}$ & OIG/97A-01
\end{tabular}




\section{Contract Audit Reports}

\begin{tabular}{llcl}
\hline OIG & Contractor/ & Questioned & Funds Put to \\
Issue Date & Contract Number & Costs & Better Use \\
\hline
\end{tabular}

4/1/97 Fauske and Associates, Inc.

RS-RES-96-071

0

0

4/10/97 Parameter, Inc.

NRC-03-93-026

0

0

4/14/97 Purdue Research Foundation/Scientech

RS-RES-96-071

0

$\$ 8,163$

5/20/97 University of Maryland/Scientech

RS-RES-96-071

0

0

6/5/97 Materials Engineering Associates, Inc.

NRC-04-88-072

0

0

6/5/97 Materials Engineering Associates, Inc.

NRC-04-88-072

0

0

6/5/97 Scientech, Inc.

RS-RES-96-071

0

$\$ 24,350$

6/9/97 Westinghouse Electric Corporation

NRC-04-90-085

0

0

6/19/97 Automation Management Consultants, Inc.

NRC-39-88-230

0

6/26/97 Science and Engineering Associates, Inc.

NRC-04-87-400

NRC-04-89-051

0

0

7/8/97 Science Applications International Corp

NRC-02-87-004

0

0

7/24/97 Westinghouse Electric Corporation

NRC-04-90-085

NRC-04-91-049

NRC-04-91-071

0

0

8/4/97 Westinghouse Electric Corporation

NRC-04-85-103

NRC-04-90-085

NRC-04-91-049

0

0 
Contract Audit Reports (continued)

\begin{tabular}{|c|c|c|c|}
\hline $\begin{array}{l}\text { OIG } \\
\text { Issue Date }\end{array}$ & $\begin{array}{l}\text { Contractor/ } \\
\text { Contract Number }\end{array}$ & $\begin{array}{l}\text { Questioned } \\
\text { Costs }\end{array}$ & $\begin{array}{l}\text { Funds Put to } \\
\text { Better Use }\end{array}$ \\
\hline $8 / 6 / 97$ & $\begin{array}{l}\text { I-NET, Incorporated } \\
\text { NRC-33-91-219 } \\
\text { NRC-33-92-340 }\end{array}$ & 0 & 0 \\
\hline 9/17/97 & $\begin{array}{l}\text { Advanced Systems Technology, Inc. } \\
\text { NRC-04-91-047 }\end{array}$ & 0 & 0 \\
\hline $9 / 22 / 97$ & $\begin{array}{l}\text { Maxima/Technassociates, Inc. } \\
\text { NRC-33-86-266 }\end{array}$ & $\$ 118,010$ & 0 \\
\hline 9/24/97 & $\begin{array}{l}\text { The Pennsylvania State University } \\
\text { RS-RES-96-071 }\end{array}$ & 0 & 0 \\
\hline 9/29/97 & $\begin{array}{l}\text { Comex Corporation } \\
\text { NRC-03-93-026 } \\
\text { NRC-03-93-036 } \\
\text { NRC-26-93-290 }\end{array}$ & 0 & 0 \\
\hline 9/30/97 & $\begin{array}{l}\text { I-NET, Incorporated } \\
\text { NRC-33-91-186 } \\
\text { NRC-33-91-219 }\end{array}$ & 0 & 0 \\
\hline 9/30/97 & $\begin{array}{l}\text { Ruland Associates, Inc. } \\
\text { NRC-33-95-173 } \\
\text { NRC-33-95-184 }\end{array}$ & 0 & 0 \\
\hline 9/30/97 & $\begin{array}{l}\text { Science Applications International Corp. } \\
\text { NRC-02-87-004 }\end{array}$ & 0 & 0 \\
\hline TOTALS & & $\$ 131,329$ & $\$ 32,513$ \\
\hline
\end{tabular}




\section{AUDIT TABLES}

During this reporting period, the OIG analyzed 21 contract audit reports issued by the DCAA. The following tables depict the cost savings from this work.

Table I. Post-Award Findings

\begin{tabular}{llcc}
\hline \multicolumn{4}{c}{ OIG Reports Containing Questioned Costs } \\
April 1, 1997 - September 30, 1997
\end{tabular}


Table II. Pre-Award Findings

\begin{tabular}{|c|c|c|c|}
\hline \multicolumn{4}{|c|}{$\begin{array}{c}\text { OIG Reports Issued with Recommendations } \\
\text { That Funds Be Put to Better Use } \\
\text { April 1, } 1997 \text { - September 30, } 1997\end{array}$} \\
\hline & Reports & $\begin{array}{l}\text { \# of } \\
\text { Reports }\end{array}$ & $\begin{array}{l}\text { Dollar } \\
\text { Value }\end{array}$ \\
\hline A. & $\begin{array}{l}\text { For which no management decision } \\
\text { has been made by the commencement } \\
\text { of the reporting period }\end{array}$ & 0 & 0 \\
\hline B. & Which were issued during the reporting period & $5 *$ & $\$ 32,513$ \\
\hline & Subtotal $(A+B)$ & 5 & $\$ 32,513$ \\
\hline C. & $\begin{array}{l}\text { For which a management decision } \\
\text { was made during the reporting period: }\end{array}$ & & \\
\hline & $\begin{array}{l}\text { (i) dollar value of recommendations } \\
\text { that were agreed to by management }\end{array}$ & 5 & $\$ 32,513$ \\
\hline & $\begin{array}{l}\text { (ii) dollar value of recommendations } \\
\text { that were not agreed to by management }\end{array}$ & 0 & 0 \\
\hline D. & $\begin{array}{l}\text { For which no management decision } \\
\text { had been made by the end of the reporting period }\end{array}$ & 0 & 0 \\
\hline E. & $\begin{array}{l}\text { For which no management decision } \\
\text { was made within } 6 \text { months of issuance }\end{array}$ & 0 & 0 \\
\hline
\end{tabular}

* Three pre-award reports reported that zero funds were available for better use. 


\section{ABBREVIATIONS}

AIGA Assistant Inspector General for Audits

AIGI

Assistant Inspector General for Investigations

AmEx

American Express

AMS

Applied Management Systems, Inc.

ANS

American Nuclear Society

ATM

Automated Teller Machine

CFR

Code of Federal Regulations

CRT

Citizen's Review Team

DCAA

U.S. Defense Contract Audit Agency

DOE

U.S. Department of Energy

DOJ

U.S. Department of Justice

EDO

Executive Director for Operations

EPA

Environmental Protection Agency

FAR

Federal Acquisition Regulation

FFRDC

Federally Funded Research and Development Center

FMFIA

Federal Managers' Financial Integrity Act

FOIA

Freedom of Information Act

FY

Fiscal Year

HLW

High-Level Waste

IG

Inspector General

ISA

Independent Safety Assessment

ISAT

Independent Safety Assessment Team

LSS

Licensing Support System

MD

Management Directive

Millstone

MOU

Millstone Nuclear Generating Station, Unit 1, New London County, CT

MYAPS

Memorandum of Understanding

NRC

Maine Yankee Atomic Power Station

NRR

U.S. Nuclear Regulatory Commission

OIG

Office of Nuclear Reactor Regulation

PFCRA Program Fraud Civil Remedies Act

RPS

Reactor Program System

SECY

Office of the Secretary

SMT

Senior Management Team

USC

United States Code 


\section{GLOSSARY}

\section{Event Inquiry}

An event inquiry is an investigative product documenting the examination of events or agency actions that do not focus specifically on individual misconduct. These reports identify institutional weaknesses that led to or allowed a problem to occur. This type of investigative effort was previously referred to as an inspection.

\section{Executive Council}

As part of a management restructuring, the Commission formed an Executive Council to ensure integration of agency planning, budgeting, financial and human resource management, information technology, and programmatic decisions. The Executive Council is chaired by the Executive Director for Operations, and includes the Chief Information Officer and Chief Financial Officer.

\section{Financial Audit}

A financial audit assesses the effectiveness of internal control systems, transaction processing, financial systems, and contracts.

\section{Funds Put to Better Use}

Funds identified in audit recommendations that could be used more efficiently by avoiding unnecessary expenses.

\section{Hotline}

A toll-free telephone number (1-800-233-3497) for reporting incidents of possible fraud, waste, and abuse to the NRC Office of the Inspector General. 


\section{Management Decision}

A final decision based on management's response to audit recommendations and findings.

\section{Material Weakness}

A specific instance of noncompliance with the FMFIA of sufficient importance to be reported to the President and the Congress. A weakness that would significantly impair the fulfillment of an agency component's mission; deprive the public of needed services; violate statutory or regulatory requirements; significantly weaken safeguards against waste, loss, unauthorized use, or misappropriation of funds, property, or other assets; or result in a conflict of interest.

\section{Special Evaluation Report}

An OIG audit report that examines the implications of NRC programs that affect national issues, such as high-level radioactive waste disposal, nuclear power plant decommissioning, or the use of radiation by the medical community in treating disease. Agency tracking of recommendations is not required.

\section{Questioned Cost}

A cost questioned as a result of an alleged violation of law, regulation, contract, or agreement governing the expenditure of funds (costs unsupported by adequate documentation or funds for a particular purpose that are unnecessary or unreasonable.) 